\title{
Удосконалена методика оцінювання системи відновлення озброєння та військової техніки окремої механізованої
} бригади

\author{
Олександр Сампір * 1 А \\ А Національний університет оборони України імені Івана Черняховського, м. Київ, Україна
}

Received: October 8, 2021 | Revised: October 21, 2021 | Accepted: October 30, 2021

DOI: $10.33445 /$ sds.2021.11.5.16

\begin{abstract}
Анотація
Основними джерелами забезпечення військ (сил) озброєнням та військовою технікою (ОВТ) в ході ведення бойових дій є: виробництво (закупівля) ОВТ; відновлення пошкодженого ОВТ; використання завчасно створеного резерву (непорушних запасів) ОВТ. Додатковими джерелами забезпечення військ ОВТ у особливий період можуть бути: техніка, що постачається з національної економіки; надходження ОВТ в рамках допомоги від країнпартнерів; трофейне ОВТ. Але, як свідчить досвід ведення бойових дій під час проведення антитерористичної операції на території Донецької та Луганської областей, безпосередньо під час проведення операції (бойових дій) забезпечення військ ОВТ здійснюється, головним чином, за рахунок відновлення ОВТ, яке вийшло з ладу через бойові чи експлуатаційні причини. Це пов'язано з фінансово-економічними можливостями держави, перевищенням термінів експлуатації ОВТ, потребою у швидкому постачанні справного ОВТ для підтримання необхідного рівня бойової готовності підрозділів до виконання поставлених завдань та рядом інших чинників, що впливають на наявність та стан ОВТ в підрозділах та військових частинах. Виконання завдання щодо вчасного відновлення пошкодженого озброєння в ході бою покладається на систему відновлення озброєння та військової техніки, яка являє собою складну (велику) систему, що містить підсистему управління та виконавчу підсистему, основою якої $\epsilon$ сили і засоби системи відновлення ОВТ. У загальному випадку під силами і засобами системи відновлення ОВТ потрібно розуміти особовий склад ремонтновідновлювальних органів та засоби технічної розвідки, евакуації, ремонту ОВТ, що використовуються для їх вчасного виявлення, проведення навантажувальнорозвантажувальних та транспортувальних робіт, ремонту та підготовки до бойового використання тощо. Для ефективної роботи всіх складових цієї складної системи необхідне завчасне планування та попереднє прогнозування щодо виробничих можливостей цих підрозділів. Тому в статті пропонуються шляхи удосконалення науково-методичного апарату щодо оцінювання системи відновлення та військової техніки.
\end{abstract}

Ключові слова: система відновлення, озброєння та військова техніка, технічна розвідка, евакуація, ремонт, можливості.

\section{Постановка проблеми}

В ході ведення бойових дій підрозділами Збройних Сил певна кількість зразків ОВТ може виходити 3 ладу $[1,2]$, що зумовлюватиме зниження боєздатності військ. Зважаючи на це їх успіх значною мірою залежатиме від функціонування системи відновлення ОВТ. Однак, проведений аналіз свідчить, що у багатьох випадках склад сил і засобів системи відновлення ОВТ не повною мірою відповідав потребам забезпечуваних військ [3]. Особливо це стосується батальйонних тактичних груп, які активно застосовувались під час виконання завдань в АТО, та не мали постійної організаційної структури, а їх склад визначався

\footnotetext{
1 * Corresponding author: ад’юнкт кафедри технічного забезпечення, e-mail: sampir1984@ukr.net, ORCID: 0000-0002-3564-1997
} 
в залежності від завдань та умов виконання тієї чи іншої бойової задачі. Причини такої невідповідності викликані не лише обмеженими фінансово-економічними можливостями держави та недоліками у роботі штабів, які планують ці бойові дії. Часто вони пов'язані 3 недосконалістю методичного апарату, який використовувався для визначення необхідного складу зазначених сил і засобів, зокрема складу ремонтновідновлювальних органів (РВО).

Очевидно, що успіх операції значною мірою залежить від величини втрат, яких зазнаватимуть війська. Якщо ці втрати перевищуватимуть допустимий рівень, при цьому не буде здійснюватися їх поповнення, війська будуть втрачати боєздатність. Тому, функціонування системи відновлення ОВТ повинно спрямовуватися на створення необхідних умов для підтримання військ у боєздатному стані. Для отримання інформації щодо укомплектованості військ (сил) ОВТ $\epsilon$ потреба в постійному оцінюванні системи відновлення ОВТ для обґрунтування складу сил і засобів системи відновлення ОВТ та ефективного виконання поставлених завдань щодо недопущення зниження боєздатності військ в ході виконання бойових завдань.

\section{Аналіз останніх досліджень та публікацій}

Дослідженню питань оцінювання складних систем такого типу присвячена ціла низка робіт, але дані роботи не враховують певні процеси впливу на ефективність системи відновлення. Зокрема в роботі [4] запропонована методика оцінювання ефективності функціонування системи відновлення. Суть якої полягає в отриманні відомості про надійність відновлення озброєння та військової техніки за номенклатурою в кожній ланці структури системи відновлення, кількості відновлених зразків озброєння та військової техніки на кожному рівні ієрархії, кількості неохоплених ремонтно-відновлювальними роботами зразків озброєння та військової техніки в кожній ланці, кількості працездатних зразків озброєння та військової техніки на кожну добу операції (бойових дій). Методика дозволяє варіювати кількістю ремонтних бригад і їх розподілом за ланками структури. В роботі [5], запропоновано математичну модель оцінювання ефективності функціонування системи відновлення ОВТ і забезпечення матеріальними засобами за величиною імовірності виконання комплексу робіт, які виконуються за заданий час. Для цього використано напівмарковську модель функціонування підсистеми відновлення озброєння та військової техніки і забезпечення матеріальними засобами в загальній системі логістики Збройних Силах України. Часткове опрацювання цієї проблеми розглянуто також у публікації [6], яка присвячена підвищенню ефективності проведення заходів з технічної розвідки шляхом використання комплексного способу виконання завдань. Автор використовує теорію ймовірності як апарат для підтвердження своїх наукових результатів. А у роботі [7] запропоновано метод моделювання на основі комплексного підходу, що базується на побудові і дослідженні математичної моделі системи забезпечення боєздатності парку ОВТ угруповання військ. Математична модель розроблена з урахуванням усієї можливої сукупності зовнішніх чинників, які впливають на систему, що характерні для умов воєнного часу, в першу чергу чинників, які обумовлюють завдання пошкоджень зразкам ОВТ i різке зростання потреб у боєприпасах і елементах комплектів ЗІП. В роботі [8] розкривається формалізований взаємо-зв'язок величини бойового потенціалу військ та результатів функціонування системи їх забезпечення ОВТ, зокрема підсистем відновлення та резерву. Запропонований спосіб може використовуватися під час прогнозування стану озброєння та військової техніки в операції, а також під час проведення досліджень, спрямованих на обгрунтування потрібного складу ремонтно-відновлювальних частин та підрозділів, потрібної величини резерву ОВТ для підтримання заданого рівня боєздатності 
військ, а в роботі [9] розглянута методика прогнозування потоку ремонтного фонду який являється одним із найважливіших показників для оцінювання готовності системи відновлення ОВТ за усередненими даними та володіє більш високою вірогідністю, так як в ній більш повно враховуються оперативнотактичні фактори і результати досліджень по надійності і живучості ОВТ. У роботі [10] запропоновано проводити оцінювання можливості виконання заходів виїзними групами з ремонту озброєння та військової техніки за допомогою одноканальної системи масового обслуговування з очікуванням, що на думку автора дозволить врахувати випадковий характер виникнення відмов ОВТ, час надходження у відповідний РВО та час відновлення пошкоджених зразків ОВТ, а робота [11] присвячена створенню автоматизованої системи управління технічним забезпеченням. Також опрацювання даної проблематики було представлено у [12] де проведений аналіз запропонованих моделей виробничого розподілу та описані основні характеристики вибраних моделей, а у роботі [13] розробленні рекомендації щодо покращення тактико-технічних характеристик рухомих засобів відновлення військової автомобільної техніки, які на думку автора забезпечать їх застосування у різних формах та способах бойових дій, а у [14] розроблений методичний підхід до оцінювання економічної ефективності ремонту зразків ОВТ. Даний підхід враховує два напрямки: фінансовоекономічні витрати на ремонт ОВТ в стаціонарних умовах та в рухомих ремонтновідновлювальних військових частинах. Зменшення фінансово-економічних витрат буде залежати від скорочення витрат на матеріально-технічні засоби і за рахунок підвищення якості ремонту. Таким чином, стаціонарна і рухома складові відновлення ОВТ забезпечують високу ефективність ремонту ОВТ в мирний час і в особливий період.

\section{Постановка завдання}

Роботи попередників внесли значний вклад в науку і були направлені на дослідження динаміки функціонування системи відновлення ОВТ в ході моделювання бойових дій. Основним інструментом для дослідження вказаної системи була теорія масового обслуговування, а сама система відновлення ОВТ була представлена як система масового обслуговування. Але в ході аналізу остатніх досліджень і публікацій було виявлено ряд питань, які не враховані в роботах попередників, а саме миттєва ймовірність та інтенсивність виявлень пошкоджених зразків ОВТ під час визначення можливостей 3 Виклад основного матеріалу

Кінцевою метою функціонування системи відновлення ОВТ $є$ підтримання визначеного рівня боєздатності військових частин (підрозділів) за рахунок забезпечення цих підрозділів працездатними зразками ОВТ після проведення комплексу заходів з їх відновлення [15]. технічної розвідки комплексним способом з використанням безпілотних літальних апаратів (БпЛА) та можливі втрати особового складу для визначення виробничих можливостей ремонтно-відновлювальних органів з ремонту ОВТ.

Отже, такі обставини вимагають вирішення актуального наукового завдання, яке полягає в удосконаленні методики оцінювання системи відновлення озброєння та військової техніки окремої механізованої бригади для формування єдиних підходів до визначення раціонального складу сил i засобів з відновлення ОВТ, що і буде метою статті.
Оцінка ефективності виконання заходів з відновлення ОВТ можлива, коли визначено показник її ефективності, тобто кількісну міру оцінки досягнення мети функціонування системи відновлення ОВТ. Показник ефективності системи повинен відповідати ряду вимог: бути обчислюваним, його 
значення можуть бути розмірними або безрозмірними величинами, які дозволяють кількісно оцінювати ефект застосування системи; бути відповідним (адекватним) меті операції; задовольняти вимогам змістовності (повноти); бути чутливим. Форма показника повинна бути найпростішою, а його зміст відповідати здоровому глузду [16].

Виходячи з мети організації процесу відновлення ОВТ, для ії оцінювання пропонується використовувати узагальнений показник ефективності роботи системи відновлення ОВТ $W_{\text {, }}$, який розраховується за формулою:

$$
W_{\text {уз }}=\sum_{i=1}^{3} \beta_{i} K_{i}
$$

де $W_{\text {रK }^{-}}$ узагальнений

показник ефективності роботи системи відновлення ОВТ омбр;

$K_{i}$ - часткові показники ефективності функціонування $i-і$ підсистеми системи відновлення ОВТ;

$$
\beta_{i} \text { - коефіцієнт важливості підсистем; }
$$

Узагальнений показник ефективності роботи системи відновлення ОВТ відображає кінцеву мету відновлення ОВТ, має чітко виражену оперативно-тактичну сутність і достатню наочність, а результат цієї математичної залежності легко порівняти 3 нормативними показниками забезпечення ОВТ в підрозділах.

3 метою оцінки ефективності виконання заходів з технічної розвідки, евакуації та ремонту використано показники, які характеризуються коефіцієнтом охоплення визначеного обсягу пошкоджених зразків ОВT, які підлягають відновленню силами та засобами РВО $\left(K_{o x}\right)$ :

для оцінки ефективності виконання заходів з технічної розвідки:

$$
K_{\text {ox TXP }}=\frac{N_{T \times P ~ j i}}{N_{\text {gpm } i}^{+}}
$$

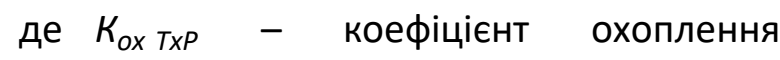
органами ТхР визначеного обсягу пошкоджених зразків ОВТ;
$N_{\text {Tх } \text { j } i}-$ кількість пошкоджених зразків OBT, що буде охоплена органами технічної розвідки (ОТхР) $j$-го РВО за $i$-ту добу;

$N_{\text {gpm i }}^{+}$- кількість пошкоджених зразків ОВТ, $j$-го РВО за $i$-ту добу, що потребує виявлення;

для оцінки ефективності виконання заходів з евакуації:

$$
K_{o x E B}=\frac{N_{E B} j i}{N_{E B i}^{+}}
$$

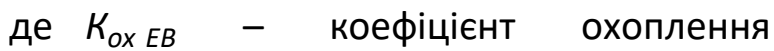
евакуаційними засобами (Е3) $j$-го РВО визначеного обсягу ремонтного фонду (РемФ) ОВТ;

$N_{E B ~ j i}-$ кількість пошкоджених зразків ОВТ, що буде евакуйована ЕЗ $j$-го РВО за $i$-ту добу;

$N_{E B}^{+} i_{-}$- обсяг евакуаційного фонду ОВТ, що прогнозується для евакуації Е3 $j$-го РВО за $i$-ту добу.

для оцінки ефективності виконання заходів з ремонту:

$$
K_{\text {ox } P}=\frac{N_{P j i}}{N_{\Pi P}^{+} i}
$$

де $K_{\text {ох }}$ - коефіцієнт охоплення $j$-м РВО визначеного обсягу РемФ ОВТ;

$N_{P}$ j $i$ - кількість пошкоджених зразків ОВТ, що буде відремонтована $j$-м РВО за $i$-ту добу;

$N_{П Р}^{+} ;$- обсяг РемФ ОВТ що прогнозується для ремонту $j$-м РВО за $i$-ту добу.

Використання запропонованих показників дає змогу оцінити ефективність функціонування системи відновлення ОВТ в цілому та її вплив на рівень забезпечення підрозділів працездатними зразками ОВТ в ході ведення омбр бойових дій, а результат розрахунків порівняти з нормативними показниками укомплектованості працездатними зразками ОВТ 3 метою визначити рівня боєздатності омбр.

Одним із основних етапів реалізації удосконаленої методики оцінювання системи відновлення $\epsilon$ визначення можливостей РВО з технічної розвідки (ТХР) пошкоджених зразків ОВТ яка запропонована в роботі [6]. 
Технічна розвідка зразків ОВТ, які вийшли 3 ладу, $\epsilon$ першим етапом комплексу робіт 3 відновлення ОВТ без якої подальше виконання завдань з евакуації та ремонту пошкоджених зразків ОВТ $є$ неможливим. На даний час організація ТХР ремонтновідновлювальними підрозділами військових частин не в повній мірі відповідає вимогам ведення бойових дій та розвитку науковотехнічної бази країни [17]. Від успішної розвідки пошкоджених зразків ОВТ буде залежати подальше виконання усіх інших заходів, які спрямовані на завантаження ремонтного органу РемФ.

Технічна розвідка в механізованих (танкових) підрозділах здійснюється виключно наземним способом використовуючи для цього пункти технічного спостереження батальйону та групи технічної розвідки (ГРР) військової частини. Але зазначені підрозділи зазвичай не в змозі розвідати всі пошкоджені зразки ОВТ, які з тієї або іншої причини вийшли 3 ладу або отримали пошкодження. Найчастіше це відбувається через ландшафт місцевості, який обмежує дальність прямої видимості та знижує ефективність використання штатних засобів спостереження. Це призводить до втрати часу під час функціонування усієї системи відновлення ОВТ та в результаті впливає на боєздатність підрозділу в інтересах якого працює РВО.

Технічна розвідка проводиться з метою: пошуку й уточнення районів (місць) зосередження найбільшої кількості ОВТ, що вийшли з ладу [18], і місцевості, на якій вона знаходиться на безпечність; визначення стану зразків ОВТ, що вийшли з ладу, характеру i обсягу робіт з їх відновлення; уточнення шляхів евакуації ОВТ, районів (місць) розміщення (розгортання) і шляхів переміщення ремонтних підрозділів; визначення стану місцевих ремонтних та інших підприємств щодо можливості використання їх для ремонту ОВТ; визначення місцезнаходження і можливості використання залишеного противником ОВТ і технічного майна; ведення інженерної та радіаційної, хімічної та біологічної розвідки на шляхах евакуації, у районах розгортання ремонтних засобів i на шляхах їх переміщення; надання допомоги пораненим і евакуації загиблих [19-22].

Як це зазначено в [6] можливості РВО під час ведення наступального бою визначаються на підставі відношення загального часу роботи групи (без урахування часу переміщення) до часу визначення характеру пошкодження та прийняття рішення стосовно пошкодженого зразка ОВТ. Кількість пошкоджених зразків ОВТ $N_{\text {TхР } j i}$, які можна розвідати рухомим органом ТхР відповідно [23], можна визначити за формулою:

$$
N_{T x P j i}=\frac{t_{p}}{T_{p}}
$$

де $t_{p}$ - час ведення технічної розвідки ТхР без урахування часу на переміщення;

$T_{p}$ - час, потрібний рухомому органу ТхР для виконання заходів щодо розвідки одного пошкодженого зразка ОВТ.

Аналіз застосування збройних сил провідними країнами світу у локальних війнах та збройних конфліктах та досвід отриманий підрозділами Збройних Сил України під час виконання завдань в операції Об'єднаних сил на території Донецької та Луганської областей довів про необхідність застосування безпілотних авіаційних комплексів (БпАК) [6, 24-27].

Застосування безпілотних літальних апаратів в ГТР може бути складним завданням, але матиме важливе значення для виконання завдань з TxP [6, 28-32]. Але це надасть ряд переваг підрозділам, які виконують дані завдання [6].

Для підтвердження ефективності виконання завдань 3 ТхР комплексним способом використано ряд критеріїв.

Коли здійснюється пошук пошкоджених зразків ОВТ окремими пошуковими періодами, важливим критерієм оцінки ефективності спостереження під час пошуку $\epsilon$ миттєва ймовірність $g$ виявлення 
пошкодженого зразка ОВТ у визначеній смузі шляхом спостереження [6].

Якщо в процесі проведення пошуку пошкоджених зразків ОВТ здійснюється безперервне спостереження, важливим критерієм для оцінювання ефективності $\epsilon$ миттєва ймовірність $\gamma d t$ виявлення протягом короткого проміжку часу $d t$. При цьому величина $\gamma \in$ інтенсивністю кількості виявлень [6].

Розглянуті характеристики

$\epsilon$
статистичними, тобто можуть бути знайдені з досвіду [33, 34]. Для цього використовують формули [6]:

$$
g=\frac{1}{\bar{n}}, \gamma=\frac{1}{\bar{t}}
$$

де $\bar{n}$ - математичне очікування кількості обльотів, яке забезпечує виявлення пошкодженого зразка ОВТ приладом розвідки;

$\bar{t}$ - математичне очікування часу, за який забезпечується виявлення цілі з моменту запуску БпАК;

На завершальному етапі оцінювання можливостей з ТхР для нормального закону розподілу $P(R)$ інтенсивність виявлення обєктів $f$ можна визначити згідно формули [6]:

$$
f=\frac{\frac{1}{\sqrt{2 \pi \sigma R}} e^{-\frac{\left(R-m_{R}\right)^{2}}{2 \sigma_{R}{ }^{2}}}}{\frac{1}{2}\left[1+\frac{R-m_{R}}{\sqrt{2 \sigma_{R}}}\right]}
$$

де $f$ - інтенсивність виявлення об'єкту за дальністю;

$R$ - дальність дії засобів повітряної розвідки.

Наступним етапом реалізації удосконаленої методики оцінювання системи відновлення ОВТ $\epsilon$ визначення середньодобових можливостей ремонтновідновлювальних підрозділів (частин) 3 ремонту ОВТ з урахуванням втрат особового складу, з метою обґрунтування необхідної кількості спеціалістів-ремонтників в ході ведення бойових дій омбр.

Для визначення виробничих можливостей ремонтно-відновлювальних підрозділів (частин) використовуються ряд методик. Так, в роботі [35] запропоновано використовувати підходи та основні положення теорії масового обслуговування. Але, використання даних методик безпосередньо в органах військового управління для планування застосування ремонтно-відновлювальних підрозділів (частин) у деякій мірі ускладнено, в першу чергу в наслідок значного обсягу розрахунків, які необхідно виконати. В $[23,36]$ запропоновано підхід, використання якого надасть інформацію, щодо середньодобових можливостей ремонтно-відновлювальних підрозділів (ремонтних рот, ремонтновідновлювальних батальйонів), тимчасових органів відновлення (ремонтних та ремонтноевакуаційних груп) з ремонту ОВТ:

$$
N_{P j i}=\frac{n t}{H}
$$

де, $N_{P \text { j } i}-$ кількість пошкоджених зразків ОВТ, що буде відремонтована $j$-м РВО за $i$-ту добу;

$n$ - кількість фахівців ремонтників, які залучені для проведення ремонтних робіт, чол.;

$t$ - середній час продуктивної роботи, год.;

$H$ - трудомісткість ремонтних робіт, люд.·год. на зразок.

Використання математичної залежності (8) для визначення середньодобових можливостей з ремонту під час проведення навчань в органах військового управління та проведений аналіз умов виконання завдань ремонтно-відновлювальними підрозділами (частинами) дозволив визначити, що отримані результати мають значні неточності.

Основний напрям удосконалення існуючого методичного підходу полягає в обґрунтуванні кількості фахівців-ремонтників $(n)$, які будуть залучені для проведення ремонтних робіт.

В математичній залежності враховується кількість фахівців-ремонтників, які входять до складу ремонтного підрозділу або екіпажу рухомого засобу технічного обслуговування та ремонту. Але, досвід виконання завдань ремонтно-відновлю- 
вальними підрозділами в зоні проведення антитерористичної операції вказує на необхідність врахування під час визначення кількості фахівців-ремонтників $n$ імовірності середньодобових санітарних, безповоротних та психогенних втрат серед особового складу ремонтних підрозділів [37, 38].

Для визначення середньодобових санітарних та безповоротних втрат особового складу доцільно використовувати методикою, яка використовуються у військах для розрахунку цих показників. Дана методика враховує умови обстановки, тривалість та інтенсивність бойових дій, місце та роль підрозділу у виконанні бойових завдань, тощо. 3 метою врахування всіх чинників в методиці визначаються нормативні коефіцієнти .

Використання цих коефіцієнтів дозволяє під час визначення кількості фахівців ремонтників, які можуть бути залучені для проведення ремонтних робіт врахувати імовірні санітарні та безповоротні втрати особового складу.

Але, досвід виконання завдань особовим складом ремонтно-відновлювальних підрозділів в зоні проведення АТО показав [39], що лише близько 15...20\% фахівцівремонтників, які виконували завдання під артилерійським та мінометним обстрілами противника, або після візуального спостереження пошкоджених зразків ОВТ були спроможні зберегти здатність до активних дій 3 виконання поставлених завдань. Тому виникає необхідність врахування психогенних втрат особового складу ремонтно-відновлювальних підрозділів під час визначення виробничих можливостей даних підрозділів.

Врахування визначених чинників під час розрахунку виробничих можливостей РВО 3 ремонту надасть можливість скорегувати значення кількості фахівців ремонтників $(n)$, які можуть бути залучені для проведення ремонтних робіт:

$$
N_{P j i}=\frac{\left(n-B_{C i}-B_{6 i}-B_{\Pi C i}\right) t}{H}
$$

де $B_{C \mathrm{i}}$ - середньодобові санітарні втрати особового складу у кожному і-му елементі бойового порядку, чол.;

$\mathrm{B}_{\text {Бі }}$ - середньодобові безповоротні втрати особового складу у кожному і-му елементі бойового порядку, чол.;

$\mathrm{B}_{\text {ПСі }}$ - середньодобові психогенні втрати особового складу, чол.;

Таким чином впровадження запропонованого підходу до врахування імовірних втрат особового складу під час визначення виробничих можливостей ремонтно-відновлювальних підрозділів дозволяє на етапі оцінювання обстановки 3 визначення можливостей ремонтновідновлювальних підрозділів з ремонту ОВТ отримати обґрунтовані дані, щодо кількості фахівців-ремонтників, які потрібно залучати для проведення ремонтних робіт.

В подальшому $\epsilon$ необхідність корегування методики визначення виробничих можливостей ремонтно-відновлюваних підрозділів з урахуванням втрат особового складу та рівня професійної підготовленості фахівців ремонтників.

\section{Висновки}

Таким чином в статті запропоновано удосконалено методику оцінювання системи відновлення озброєння та військової техніки окремої механізованої бригади, яка на відміну від існуючої враховує миттєву ймовірність та інтенсивність виявлень пошкоджених зразків ОВТ під час виконання завдань з технічної розвідки ОВТ. Також зазначена методика дозволяє визначити виробничі можливості ремонтновідновлювальних підрозділів з проведення ремонтних робіт на зразках ОВТ 3 урахуванням середньодобових санітарних, безповоротних та психогенних втрат особового складу, які можуть виникнути під час ведення бойових дій окремою 
механізованою бригадою. Також визначено узагальнений показник ефективності системи відновлення ОВТ та часткові показниківи ефективності, які дозволять обґрунтувати раціональну структуру системи відновлення ОВТ для потрібної військової ланки.

\section{Список використаних джерел}

1. Положення про забезпечення озброєнням, військовою технікою, боєприпасами та іншими матеріальними засобами з'єднань і частин внутрішніх військ Міністерства внутрішніх справ для виконання службовобойових завдань в особливий період : постанова КМ України від 10 жовтня 2010 р. № 1309: станом на 20 лист. 2021 p. URL: https://zakon.rada.gov.ua/laws/show/13092001-п\#Техt (дата звернення: 20.11.2021).

2. Павловський О. В. Прогнозування величини втрат озброєння та військової техніки під час операцій (бойових дій) / О. В. Павловський // Системи озброєння і військова техніка. 2015. - № 4. - C. 116-118. - URL: http://nbuv.gov.ua/UJRN/soivt_2015_4_33.

3. Баранов Ю., Баранов А., Спільник В., \& Данилов Д. (2020). Вплив процесів технічного обслуговування та відновлення на ефективність управління технічним станом військової техніки в провідних країнах світу та Збройних Сил України. Збірник наукових праць Національної академії Державної прикордонної служби України. Серія: військові та технічні науки, 81(3), 302-315. DOI : 10.32453/3.v81i3.478

4. Дачковський В.О., Коцюруба В.І. Методика оцінювання ефективності функціонування системи відновлення озброєння та військової техніки. Сучасні інфрормачійні технології у сфері безпеки та оборони, 2020. № 1(37) C. 5-14. DOI : 10.33099/23117249/2020-37-1-5-14

5. Дачковський В. О., Стрельбіцький М.А. Математична модель функціонування системи відновлення озброєння та військової техніки. Сучасні інформачійні технології у сфрері безпеки та оборони, 2020. № 2(38) C. 87-94. DOI : 10.33099/23117249/2020-38-2-87-94

6. Сампір, О. (2021). Удосконалена методика визначення можливостей 3 технічної розвідки пошкоджених зразків озброєння та військової техніки в ході ведення бойових дій. Journal of Scientific Papers "Social Development and Security», 11(2), 141-151. DOI : 10.33445/sds.2021.11.2.14

7. Шишанов М. О. Обгрунтування методу моделювання процесу функціонування системи відновлення озброєння та військової техніки угруповання військ / Шишанов М.О., Гуляєв А.В., Шевцов М.М. // Озброєння та військова техніка, 2017, №1(13), С. 75-77

8. Павловський О. В. Прогнозування величини відверненого збитку військ, зумовленого функціонуванням системи їх забезпечення озброєнням та військовою технікою. Сучасні інформаційні технології у сфрері безпеки та оборони. 2016. № 1. C. 87-91. - URL: http://nbuv.gov.ua/UJRN/sitsbo_2016_1_19

9. Дачковський , В., Гудима , В., \& Сампір , О. (2021). Методичний підхід до прогнозування потоку ремонтного фонду зразків озброєння та військової техніки. Збірник наукових праць К'ОГОг. DOI: 10.36074/logos-26.02.2021.v1.40

10. Дачковський , В., \& Цуркан , М. (2021). Методика оцінювання можливості виконання заходів з ремонту озброєння та військової техніки. Збірник наукових пращь

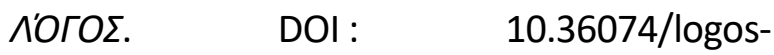
19.03.2021.v1.49

11.Арепин Ю.И. Методология создания автоматизированных систем технического обеспечения. URL: http://www.ozakaz.ru/ index.php/articles/n-25-12-2007/202n27032011-17-34

12. Дачковський, В.О. Ярошенко, О.В., Овчаренко, І.В., Сампір, О.М. Методика проектування ремонтно-відновлювальних органів. Збірник наукових праць військової академії (м. Одеса), 2020. № 13(1), ч. І, С. 210-222. 
13. Kondratyuk, I. (2021). Analysis of the development of mobile maintenance and repair of military vehicles. Journal of Scientific Papers "Social Development and Security", 11(1), 52-69. DOI : 10.33445/sds.2021.11.1.6

14. Dachkovskyi, V. Sampir, O. Horbachova Y. (2020). Methodical approach to evaluation of economic efficiency of repairing the weapons and military equipment. VUZF review, Vol. 5, No 1 , p. 22-30. DOI: 10.38188/25349228.20.1.03

15. Застосування підрозділів та військових частин технічного забезпечення. Підрозділи технічного забезпечення: Ч. І / І.Б. Кузнецов, О.В. Ярошенко, І.В. Овчаренко, В.О. Дачковський, О.Д. Яльницький, Н.К. Багдасарян, Б.Т. Кузнецов // навч. посіб. -К.: НУОУ ім. Івана Черняховського, 2017. - 136 с.

16. Барабаш Ю.Л. Основи теорії оцінювання ефективності складних систем (Методологія наукових досліджень) / Барабаш Ю. Л. - К.: НУОУ, 1999. - 40 c.

17. Про схвалення Основних напрямів розвитку озброєння та військової техніки на довгостроковий період [Текст]: постанова КМ України від 14 червня 2017 р. № 398-р // - К.: КМ України, 2017. - 14 с.

18. Застосування ремонтно-відновлюваних частин та підрозділів. Частина 2. Ремонтновідновлювана військова частина / О.В. Ярошенко, І.В. Овчаренко, В.О. Дачковський, // навч. посіб. - К.: НУОУ ім. Івана Черняховського, 2018. - 80 с.

19. Dachkovskyi, V. (2020). Formalization of problem and justification of the set of principles of construction of the system of restoration of weapons and military equipment. Journal of Scientific Papers «Social Development and Security», 10(4), 128-138. DOI: 10.33445/sds.2020.10.4.12

20. БРДМ-2. Бронированная разведывательнодозорная машина БРДМ-2. Инструкция по эксплуатации.

21. БРДМ-2. Бронированная разведывательнодозорная машина БРДМ-2. ТО и ИЭ. Книга 1. 1987.
22. БРДМ-2. Бронированная разведывательнодозорная машина БРДМ-2. ТО и ИЭ. Книга 2. 1987.

23. Оперативні розрахунки завдань технічного забезпечення (методика та приклади) / В.О. Дачковський, О.В. Ярошенко, І.В. Овчаренко, Н.К. Багдасарян // навч. посіб. - К.: НУОУ ім. Івана Черняховського, 2018. - 116 с.

24. Аналіз можливостей застосування безпілотних літальних апаратів для військових цілей / Глотов, А. Гуніна, Ю. Телещук // Збірник наукових праць Західного геодезичного товариства УТГК "Сучасні досягнення геодезичної науки та виробництва". - 2017. - № 1(33). - С. 139146.

25. Особливості та проблемні питання визначення оперативно-тактичних вимог до БПЛА з урахуванням сучасних принципів ведення воєнних(бойових) дій / В.О. Колесніков, О.Л. Глушкевич, Д. Л. Федянович // Збірник наукових праць центру воєнно-стратегічних досліджень. К.: НУОУ ім. Івана Черняховського. - 2016. № 3(58). - С. 39-43.

26. Застосування безпілотних авіаційних комплексів в інтересах обслуговування стрільби артилерії / В.М. Казаков, Ю Л. Вода // Збірник наукових праць Харківського національного університету Повітряних Сил. - 2017. - № 5 (54).

27. Особливості застосування оперативнотактичної безпілотної розвідувальної авіації у воєнних конфліктах XX століття / С. П. Мосов, С. Й. Хорошилова // Збірник наукових праць центру воєнно-стратегічних досліджень. - К.: НУОУ ім. Івана Черняховського. - 2018. - № 2(63). - С. 104109.

28. Пат. 102083 Україна, МПК (2013) F41H 7/00. Машина технічної розвідки (МТР-1) / Дачковський В.О.; - заявник і володар патенту Дачковський В.О. - № u201504517; заяв. 8.05.2015; опубл. 12.10.2015; Бюл. № 19.

29. Пат. 105092 Україна, МПК (2013) F41H 7/00. Машина технічної розвідки (МТP-2) / 
Дачковський В.О., Коцюруба В.І., Даценко І.П.; - заявник і володар патенту НУОУ - № и201506514; заяв. 2.07.2015; опубл. 10.03.2016; Бюл. № 5.

30. Методичні рекомендації командиру підрозділу по застосуванню БпАК тактичного рівня (ВП 7-46(12).01) / О.О. Павлишен, Г.М. Тимчук, Т.В. Цокур // Управління безпілотної авіації штабу Командування Повітряних Сил Збройних Сил України (м. Вінниця ), 2018. - 68 с.

31. Про затвердження Правил технічної експлуатації безпілотних авіаційних комплексів I класу державної авіації України: Наказ Міністерства оборони України від 10.08.2018 № 401).

32. Про затвердження Тимчасової настанови 3 бойового застосування БпАК класу I у Збройних Силах України . - К.: 2018. - 45 с. (Наказ Генерального штабу Збройних Сил України від 18.06.2018 № 228дск)

33. Горбунов В. А. Эффективность обнаружения цели. М., Воениздат, 1980. - 160 с.

34. Левченко М. А., Дачковський В. О. Математична модель виконання завдань 3 технічної розвідки. Міжнародний науковий журнал “Грааль науки” № 6 (Червень, 2021): за матеріалами I Міжнародної науковопрактичної конференції «Modern science: concepts, theories and methods of basic and applied research», що проводилася 25 червня 2021 року «International Centre Corporative Management» (Відень, Австрія). p. 87-90. DOI: 10.36074/grail-ofscience.25.06.2021.015
35. Dachkovskyi, V. (2019). Methodology of justification of tactical and technical requirements for movable means of repairing arms and military equipment. Journal of Scientific Papers "Social Development and Security», 9(6), 86-101. DOI: 10.33445/sds.2019.9.6.73

36. Робота заступника командира окремої механізованої бригади з озброєння під час підготовки та в ході бою (маршу): навч.метод. посіб. / В.О. Дачковський, І. В. Овчаренко, О. Д. Яльницький та ін. - К.: HУOУ, 2015. - $160 \mathrm{c}$.

37. Ягупов В. В. Методика прогнозування й розрахунку психогенних втрат серед особового складу. Військове виховання: історія, теорія та сучасність : навч. посіб. / за ред. В. В. Ягупова. - К.: Graphic\&Design, 2002. - C. 447-455.

38. Badiuk M. I. The combat stress reaction as a scientific problem of the world, and its social and medical consequences / M. I. Badiuk, O. S. Shevchuk, K. S. Gutchenko, I. G. Biryuk, T. E. Moldovan // Клінічна та експериментальна патологія. - 2016. - Т. 15, № 4. - С. 10-14. URL :

http://nbuv.gov.ua/UJRN/kep_2016_15_4_5

39 Аналіз ведення антитерористичної операції та наслідків вторгнення Російської 39. Федерації в Україну у серпні-вересні 2014 року / Генеральний Штаб Збройних Сил України, Центральний науково-дослідний інститут Збройних Сил України. URL: http://www.mil.gov.ua/content/other/ anliz_rf.pdf

\section{Усовершенствованная методика оценки системы} восстановления вооружения и военной техники отдельной
механизированной бригады

\footnotetext{
Александр Сампир * 1 А

* Corresponding author: ${ }^{1}$ адъюнкт кафедры технического обеспечения, e-mail: sampir1984@ukr.net ORCID: 0000-0002-3564-1997

А Национальный университет обороны Украины имени Ивана Черняховского, Киев, Украина
}

\section{Аннотация}

Основными источниками обеспечения войск вооружением и военной техникой (ВВТ) в ходе ведения боевых действий являются: производство (закупка) ВВТ; восстановление 
поврежденного ВВТ; использование заранее созданного резерва (незыблемых запасов) ВВТ. Дополнительными источниками обеспечения войск ВВТ в особый период могут быть: техника, поставляемая из национальной экономики; поступление ВBT в рамках помощи от странпартнеров; трофейное ОВТ. Но, как свидетельствует опыт ведения боевых действий при проведении антитеррористической операции на территории Донецкой и Луганской областей, непосредственно при проведении операций (боевых действий) обеспечение войск ВBT осуществляется, главным образом, за счет восстановления ВВТ, которое вышло из строя по боевым или эксплуатационным причинам. Это связано с финансово-экономическими возможностями государства, превышением сроков эксплуатации ВВТ, потребностью в быстром снабжении исправного ВВТ для поддержания необходимого уровня боевой готовности подразделений к выполнению поставленных задач и рядом других факторов, влияющих на наличие и состояние ВВТ в подразделениях и воинских частях. Выполнение задачи по своевременному восстановлению поврежденного вооружения в ходе боя возлагается на систему восстановления вооружения и военной техники, которая представляет собой сложную (большую) систему, содержащую подсистему управления и исполнительную подсистему, основой которой являются силы и средства восстановления ВВТ. В общем случае под силами и средствами системы восстановления ВВТ следует понимать личный состав ремонтно-восстановительных органов и средства технической разведки, эвакуации, ремонта ВВТ, которые используются для их своевременного выявления, проведения погрузочно-разгрузочных и транспортировочных работ, ремонта и подготовки к боевому использованию и т.д. Для эффективной работы всех составляющих этой сложной системы необходимо заблаговременное планирование и предварительное прогнозирование производственных возможностей этих подразделений. Поэтому в статье предлагаются пути усовершенствования научно-методического аппарата по оценке системы восстановления и военной техники.

Ключевые слова: система восстановления, вооружения и военная техника, техническая разведка, эвакуация, ремонт, возможности.

\title{
Improved methods for assessing the system of weapons and military equipment recovery of a separate mechanized brigade
}

\author{
Oleksandr Sampir * 1 A \\ * Corresponding author: ${ }^{1}$ PhD student Department of Technical Support, e-mail: sampir1984@ukr.net, ORCID: 0000-0002-3564-1997 \\ A National Defence University of Ukraine named after Ivan Cherniachovskyi, Kyiv, Ukraine
}

\begin{abstract}
The main sources of providing troops with weapons and military equipment (weapons) in the course of hostilities are: production (purchase) of weapons; restoration of damaged weapons; use of pre-established reserve (inviolable stocks) of weapons. Additional sources of armaments in a special period may be: equipment supplied from the national economy; receipt of weapons in the framework of assistance from partner countries; trophy weapons. But, as the experience of fighting during the anti-terrorist operation in the Donetsk and Luhansk regions, directly during the operations (combat operations) supply of armaments is carried out mainly through the restoration of weapons that have failed due to combat or operational reasons. This is due to the financial and economic capabilities of the state, exceeding the service life of weapons, the need for rapid supply of serviceable weapons to maintain the required level of combat readiness of units to perform tasks and a number of other factors affecting the availability and condition of weapons in units and military units. Execution of the task of timely restoration of damaged weapons during combat is entrusted to the system of restoration of weapons and military equipment, which is a complex (large) system containing a control subsystem and executive subsystem, based on forces and means of weapons recovery. In the general case, the forces and
\end{abstract}


means of the weapons recovery system should be understood as the personnel of the repair and restoration bodies and means of technical intelligence, evacuation, repair of weapons used for their timely detection, loading and unloading and transportation works, repair and preparation for combat use, etc. The effective operation of all components of this complex system requires advance planning and preliminary forecasting of the production capacity of these units. Therefore, the article proposes ways to improve the scientific and methodological apparatus for assessing the recovery system and military equipment.

Keywords: recovery system, armaments and military equipment, technical reconnaissance, evacuation, repairs, capabilities.

\section{References}

1. Regulations on the provision of weapons, military equipment, ammunition and other material means of units and units of the internal troops of the Ministry of Internal Affairs to perform combat missions in a special period: Resolution of the Cabinet of Ministers of Ukraine of October 10, 2010 №1309: as of 20 letter. 2021. Available from : https://zakon.rada.gov.ua/laws/show/13092001-p\#Text (access date: 20.11.2021)

2. Pavlovsky, O.V. (2015). Forecasting the magnitude of losses of weapons and military equipment during operations (combat operations). Weapons systems and military equipment. № 4. P. 116-118. Available from : http://nbuv.gov.ua/UJRN/soivt_2015_4_33.

3. Baranov Y., Baranov A., Spilnik V., \& Danilov D. (2020). The impact of maintenance and recovery processes on the effectiveness of management of the technical condition of military equipment in the leading countries of the world and the Armed Forces of Ukraine. Collection of scientific works of the National Academy of the State Border Guard Service of Ukraine. Series: Military and Technical Sciences, 81 (3), 302-315. DOI: 10.32453/3.v81i3.478

4. Dachkovsky, V.O., Kotsyuruba, V. I. (2020). Method of evaluation of efficiency of functioning of arms and military engineering system. Modern information technologies in the field of security and defense, № 1 (37) P. 5-14. DOI: 10.33099/2311-7249/2020-37-15-14

5. Dachkovsky, V.O., Strelbitsky, M. A. (2020). Mathematical model of functioning of system of restoration of armament and military equipment. Modern information technologies in the field of security and defense. № 2 (38) P. 87-94. DOI: 10.33099/2311-7249/2020-38-2-87-94

6. Sampir, O. (2021). Improvement of the method of determining opportunities for technical exploration of damaged samples of weapons during combat. Journal of Scientific Papers "Social Development and Security", 11(2), 141-151. DOI: 10.33445/sds.2021.11.2.14

7. Shishanov, M.O., Gulyaev, A.V., Shevtsov, M.M. (2017). Substantiation of the method of modeling the process of functioning of the system of restoration of armaments and military equipment of the grouping of troops. Weapons and military equipment, 2017, №1 (13), p. 75-77

8. Pavlovsky, O.V. (2016). Prognozuvannia velychy otvernenoho zbytku vysk, zumovlenoho funktsionuvannyam sistemy ikh zabezpechennia ozbroennyam ta voiskovoi tekhnikii. [Forecasting the magnitude of the averted loss of troops due to the functioning of the system of their provision with weapons and military equipment]. № 1. P. 87-91. Available from :

http://nbuv.gov.ua/UJRN/sitsbo_2016_1_19.9

9. Dachkovsky, V., Hudyma, V., \& Sampir, O. (2021). Methodical approach to forecasting the flow of the repair fund of samples of weapons and military equipment. Collection

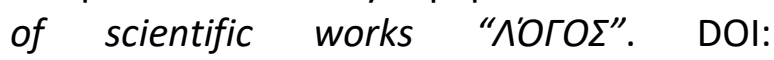
10.36074/logos-26.02.2021.v1.40

10. Dachkovsky, V., \& Turcan, M. (2021). Methods of assessing the possibility of implementing measures to repair weapons 
and military equipment. Collection of

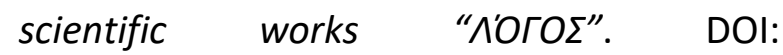
10.36074/logos-19.03.2021.v1.49

11. Arepin Yu.I. Methodology of creating automated technical support systems. Available from: http://www.ozakaz.ru/ index.php/articles/n-25-12-2007/202n27032011-17-34

12. Dachkovsky, V. O., Yaroshenko, O. V., Ovcharenko, I. V., Sampir, O.M. (2020). Methods of designing repair and restoration bodies. Collection of scientific works of the Military Academy (Odessa), No 13 (1), part I, pp. 210-222.

13. Kondratyuk, I. (2021). Analysis of the development of mobile maintenance and repair of military vehicles. Journal of Scientific Papers "Social Development and Security", 11(1), 52-69. DOI : 10.33445/sds.2021.11.1.6

14. Dachkovskyi, V. Sampir, O. Horbachova Y. (2020). Methodical approach to evaluation of economic efficiency of repairing the weapons and military equipment. VUZF review, Vol. 5, No 1, p. 22-30. DOI: 10.38188/25349228.20.1.03

15. The use of units and military units of technical support. Subdivisions of technical support: Part I / I. B. Kuznetsov, O. V. Yaroshenko, I. V. Ocharenko, B. O. Dachkovsky, O. D. Yalnytsky, N. K. Baghdasaryan, B. T. Kuznetsov // textbook. way. Kyiv: NUOU, 2017. 136 p.

16. Barabash Yu. L. Fundamentals of the theory of evaluating the effectiveness of complex systems (Methodology of scientific research). Kyiv: NUOU, 1999. 40 p.

17. On approval of the main directions of development of armaments and military equipment for the long term [Text]: Resolution of the Cabinet of Ministers of Ukraine of June 14, 2017 № 398-r.

18. Application of repair and restoration parts and units. Part 2. Repair and restoration of the military unit / O.V. Yaroshenko, I.V. Ocharenko, B.O. Dachkovsky, // textbook. way. Kyiv: NUOU, 2018. 80 p.
19. Dachkovskyi, V. (2020). Formalization of problem and justification of the set of principles of construction of the system of restoration of weapons and military equipment. Journal of Scientific Papers "Social Development and Security», 10(4), 128-138. DOI: $10.33445 / s d s .2020 .10 .4 .12$

20. BRDM-2. BRDM-2 armored reconnaissance patrol vehicle. Operating instructions.

21. BRDM-2. BRDM-2 armored reconnaissance patrol vehicle. THAT and IE. Book 1. 1987.

22. BRDM-2. BRDM-2 armored reconnaissance patrol vehicle. THAT and IE. Book 2. 1987.

23. Operational calculations of technical support tasks (methods and examples) / V.O. Dachkovsky, OV Yaroshenko, IV Ovcharenko, NK Baghdasaryan // textbook. way. Kyiv: NUOU, 2018. $116 \mathrm{p}$.

24. Glotov, A. Gunina, Yu. Teleschuk Analysis of the possibilities of using unmanned aerial vehicles for military purposes // Collection of scientific works of the Western Geodetic Society UTGC "Modern achievements of geodetic science and production". 2017. № 1 (33). P. 139-146.

25. Peculiarities and problematic issues of determining operational and tactical requirements for UAVs taking into account modern principles of military (combat) operations / V. O. Kolesnikov, O. L. Glushkevych, D. L. Fedyanovych // Collection of scientific works of the center of militarystrategic researches. Kyiv: NUOU. 2016. № 3 (58). P. 39-43.

26. Kazakov, V.M., Water, Yu. L. (2017). Application of unmanned aerial vehicles in the interests of artillery firing maintenance. Collection of scientific works of Kharkiv National University of the Air Force. № 5 (54)

27. Mosov, S.P., Khoroshilova, S.Y. (2018). Features of the use of operational and tactical unmanned reconnaissance aircraft in the military conflicts of the twentieth century. Collection of scientific works of the Center for Military and Strategic Studies. Kyiv: NUOU. № 2 (63). P. 104-109. 
28. Pat.102083 Ukraine, IPC (2013) F41H 7/00. Technical reconnaissance machine (MTR-1) / Dachkovsky V.O.; - applicant and patent holder Dachkovsky V.O. - № u201504517; application. 08/05/2015; publ. 10/12/2015; Bull. № 19.

29. Pat. 105092 Ukraine, IPC (2013) F41H 7/00. Technical reconnaissance machine (MTR-2) / Dachkovsky V.O., Kotsyuruba V.I., Datsenko I.P.; - applicant and patent holder of the NGO - № u201506514; application. 07/02/2015; publ. 10.03.2016; Bull. № 5.

30. Methodical recommendations of the commander of the unit on the use of BPAC tactical level (VP 7-46 (12). 01) / 0.0. Pavlishen, G.M. Timchuk, T.V. Tsokur // Department of Unmanned Aviation of the Air Force Command of the Armed Forces of Ukraine (Vinnytsia), 2018. 68 p.

31. About the statement of Rules of technical operation of unmanned aviation complexes of the I class of the state aviation of Ukraine. Kyiv: 2018. 36 p. (Order of the Ministry of Defense of Ukraine dated August 10, 2018 № 401).

32. On approval of the Interim Instruction on Combat Use of the Class I BPAC in the Armed Forces of Ukraine. -Kyiv: 2018. 45 p. (Order of the General Staff of the Armed Forces of Ukraine dated June 18, 2018 № 228

33. Gorbunov, V. A. Target detection efficiency. Moscow, Voenizdat, 1980. 160 p.

34. Levchenko, M. A., Dachkovsky, V.O. Mathematical model of technical intelligence tasks. International Scientific Journal "Grail of Science" № 6 (June, 2021): based on the materials of the I International Scientific and Practical Conference "Modern science: concepts, theories and methods of basic and applied research", held June 25, 2021 International Center Corporate Management (Vienna, Austria). pp. 87-90. DOI: 10.36074/grail-of-science.25.06.2021.015

35. Dachkovskyi, V. (2019). Methodology of justification of tactical and technical requirements for movable means of repairing arms and military equipment. Journal of Scientific Papers "Social Development and Security", 9(6), 86-101. DOI: 10.33445/sds.2019.9.6.73

36. The work of the deputy commander of a separate mechanized brigade for armaments during training and during the battle (march): teaching method. way. / B.O. Dachkovsky, I.V. Ovcharenko, O.D. Yalnytsky and others. Kyiv: NUOU, 2015. 160 p.

37. Yagupov V.V. Methods of forecasting and calculation of psychogenic losses among personnel. Military education: history, theory and modernity: textbook. way. / for ed. VV Yagupov. Kyiv: Graphic \& Design, 2002. P. 447-455.

38. Badiuk M. I. The combat stress reaction as a scientific problem of the world, and its social and medical consequences / M. I. Badiuk, O. S. Shevchuk, K. S. Gutchenko, I. G. Biryuk, T. E. Moldovan. 2016. T. 15, № 4. C. 10-14. Available from : http://nbuv.gov.ua/UJRN/kep_2016_15_4_5

39. Analysis of the anti-terrorist operation and the consequences of the Russian invasion of Ukraine in August-September 2014 / General Staff of the Armed Forces of Ukraine, Central Research Institute of the Armed Forces of Ukraine. Available from: http://www.mil.gov.ua/content/other/anliz _rf.pdf 